Vol 11, Issue 6, 2018

\title{
EVALUATION OF PROTECTIVE EFFECT OF BASSIA MALABARICA LEAVES AGAINST CISPLATIN- INDUCED NEPHROTOXICITY AND DOXORUBICIN-INDUCED CARDIOTOXICITY IN RATS
}

\author{
SUSHMA M ${ }^{1}$, SUJATHA $\mathrm{D}^{2}$, PRASAD KVSRG ${ }^{2 *}$ \\ ${ }^{1}$ Department of Pharmacology, CMR College of Pharmacy, Hyderabad, Telangana, India. ${ }^{2}$ Department of Pharmacology, Institute of \\ Pharmaceutical Technology, Sri Padmavati Mahila Visvavidyalayam (Womens University), Tirupati - 517 502, Andhra Pradesh, India. \\ Email: kvsrgprasad@gmail.com
}

Received: 02 April 2018, Revised and Accepted: 21 April 2018

ABSTRACT

Objective: The objective of the current investigation is to study the effect of ethanolic extract of Bassia malabarica leaves (EBML) against cisplatininduced nephrotoxicity and doxorubicin (DOX)-induced cardiotoxicity in healthy adult male Wistar rats.

Methods: Nephrotoxicity was induced by cisplatin $(7 \mathrm{mg} / \mathrm{kg}$, i.p) and cardiotoxicity was induced by DOX (15 mg/kg, i.p). In both the models, EBML $(150 \mathrm{mg} / \mathrm{kg}$ and $300 \mathrm{mg} / \mathrm{kg}$, p.o $)$ was administered for 15 days to assess the prophylactic and curative effect. Urinary parameters, biochemical parameters, and in vivo antioxidants were monitored for nephroprotective effect. For assessing cardioprotective effect serum parameters, cardiac ATPases and in vivo antioxidants were measured. A statistical significance was set at $\mathrm{p}<0.05$ which was analyzed by one-way analysis of variance followed by Tukey's multiple comparison test.

Results: The study results show that the EBML has significantly $(\mathrm{p}<0.05)$ restored the urinary parameters, serum parameters of cisplatin-induced nephrotoxic rats, and serum parameters of DOX -induced cardiotoxic rats. A significant decrease $(\mathrm{p}<0.05)$ in levels of malondialdehyde and increase in reduced glutathione and catalase were seen in both nephrotoxic and cardiotoxic rats. $\mathrm{Ca}^{+2}$ ATPase was significantly decreased and $\mathrm{Na}^{+} \mathrm{K}^{+} \mathrm{ATPase}$ was significantly increased $(\mathrm{p}<0.05)$ in the treatment groups when compared to DOX disease control group.

Conclusion: EBML showed a protective effect against cisplatin-induced nephrotoxicity and DOX -induced cardiotoxicity.

Keywords: Bassia malabarica, Cisplatin, Doxorubicin, In vitro antioxidants, In vivo antioxidants, Cardiac ATPases.

(C) 2018 The Authors. Published by Innovare Academic Sciences Pvt Ltd. This is an open access article under the CC BY license (http://creativecommons. org/licenses/by/4. 0/) DOI: http://dx.doi.org/10.22159/ajpcr.2018.v11i6.26401

\section{INTRODUCTION}

Cancer is a disease that kills more globally than tuberculosis, acquired immune deficiency syndrome, and malaria [1]. By 2030, 21.4 million new cancer cases are expected to occur globally with 13.2 million cancer deaths. The most prevalent cancers in men are prostate and lung, and in females, it includes breast, cervical, and colorectal (as per the National cancer registers). The chemotherapy of most cancers is a combination of two or more drugs. Since most of these anticancer drugs and its metabolites affect cells of vital organs (such as kidney, heart, bladder, and lungs) leading to toxicity to vital organs, search for therapeutic aid for alleviating these toxicities from natural sources like medicinal plants has become more important. Recent trends in chemotherapy also emphasize on adjuvant therapy to reduce damage to the vital organs. This prompted us to study the cardioprotective and nephroprotective activity of the selected plants simultaneously.

Medicinal plants play a significant role in ancient traditional systems of medication in many countries. In India, thousands of plant species are known to have medicinal values, and the use of different parts of several medicinal plants to cure specific ailments has been in vogue since ancient time [2].

The genus Madhuca (Sapotaceae) comprises economically important plants and is well known for their wide variety of uses. Plant Bassia malabarica (Family - Sapotaceae) flowers are used in renal diseases, fruit in rheumatism, asthma, cough [3], heart diseases, burning sensation, and ear complaints [4,5]. Seed oil was used for cooking, growth of hair, and soap making [6-8].

The review of literature reported that the bark of B. malabarica had nephron protective effect [9] and its oil decreased serum cholesterol
$(\mathrm{CH})$ and triglyceride (TG) levels of rats [10]. Review revealed that so far no studies have been undertaken on the protective effect of B. malabarica leaves (BML) against cisplatin-induced nephrotoxicity and doxorubicin (DOX)-induced cardiotoxicity. Thus, the aim of the present study was to evaluate the protective effect of ethanolic extract of BML (EBML) against cisplatin-induced nephrotoxicity and DOXinduced cardiotoxicity.

\section{METHODS}

\section{Plant material and extraction}

The leaves of B. malabarica grown in the forests of Tirumala region have been identified taxonomically and authenticated by Dr. S. Madhavachetty, Department of Botany,SVU, Tirupathi, Andhra Pradesh. Voucherspecimen of the plant was deposited in CMR College of Pharmacy, Hyderabad (voucher no- CMRCP/2014/07). Freshly collected leaves were shade dried and made into a coarse powder (Sieve No: 40). The powder was defatted with petroleum ether initially and later successively extracted with different solvents in increasing order of polarity, i.e., chloroform, ethyl acetate, and ethanol using Soxhlet apparatus for $6 \mathrm{~h}$. The extracts were dried under reduced pressure using a rotary vacuum evaporator and stored at $4^{\circ} \mathrm{C}$ for further use.

\section{Phytochemical screening}

The extracts were screened for various phytoconstituents such as alkaloids, glycosides, flavonoids, tannins, and steroids by employing standard phytochemical tests [11].

\section{Drugs and chemicals}

Cisplatin injection available as cytoplatin $(50 \mathrm{mg} / 50 \mathrm{ml})$ was procured from Cipla and DOX injection available as Adrim (2 $\mathrm{mg} / \mathrm{ml}$ ) was procured from Fresenius Kabi Oncology Ltd.; 
chemicals such as 1, 1-diphenyl-2-picrylhydrazyl (DPPH), 2, 2'-azino-bis (3-ethyl benzothiazoline-6-sulfonic acid) (ABTS), and ethylenediaminetetraacetic acid were procured from Sigma Chemical Co. India. Adenosine triphosphate (ATP) was procured from HiMedia, and the other chemicals used were of analytical grade from EMerck and SD fine. The biochemical kits used in this study were purchased from Excel, Span, and Coral Diagnostics.

\section{Experimental animals}

Healthy adult male albino rats of Wistar strain weighing 150-200 g were procured from Teena labs, Hyderabad (CPCSEA Regd. No: 177/99/CPCSEA). The rats were acclimatized to the laboratory conditions for 10 days at room temperature $\left(27 \pm 3^{\circ} \mathrm{C}\right)$ and relative humidity $(65 \pm 10 \%)$. All the rats were fed with commercially available pellet diet obtained from Amruth Foods, Pranav Agro Industries, Sangli, India, and water was given ad libitum. Rats used in this study were treated and cared for in accordance with the guidelines recommended by CPCSEA (Reg. No: 1657/PO/a/12/CPCSEA). The study was approved by the Institutional Animal Ethics Committee of CMR College of Pharmacy, Hyderabad (CPCSEA/1657/IAEC/CMRCP/ PhD14-31).

\section{Acute toxicity studies}

The acute oral toxicity study of EBML was carried in healthy adult female rats of Wistar strain. This method was done according to OECD guideline 423 , acute toxic class method [12].

\section{Preparation of solution for administration to animals}

Since the EBML was water insoluble, it was suspended in $1 \%$ carboxymethyl cellulose (CMC) solution $(75 \mathrm{mg} / \mathrm{ml})$. The suspension was prepared freshly just before administration to the animals.

\section{Treatment schedule to evaluate cisplatin-induced nephrotoxicity}

Animals were divided into seven groups $(\mathrm{n}=8)$ :

- Group I: Rats were administered with 1\% CMC (p.o) once daily for 15 days and sacrificed on the $16^{\text {th }}$ day, served as normal.

- Group II: Rats received a single dose of cisplatin (7 mg/kg, i.p) to induce nephrotoxicity onthe day 1 and were sacrificed on the $6^{\text {th }}$ day, served as cisplatin disease control.

- Groups III and IV: Rats were treated with EBML $150 \mathrm{mg} / \mathrm{kg}$ and $300 \mathrm{mg} / \mathrm{kg}$ for 15 days. On the $16^{\text {th }}$ day, rats were administered with a single dose of cisplatin $(7 \mathrm{mg} / \mathrm{kg}$, i.p) and were sacrificed on the $21^{\text {st }}$ day, served as prophylactic groups at two doses of 150 and $300 \mathrm{mg} / \mathrm{kg}$, respectively.

- Groups V and VI: Rats were administered with a single dose of cisplatin $\left(7 \mathrm{mg} / \mathrm{kg}\right.$, i.p) on the $1^{\text {st }}$ day and then treated with EBML $150 \mathrm{mg} / \mathrm{kg}$ and $300 \mathrm{mg} / \mathrm{kg}$ for 15 days (i.e., $6^{\text {th }}$ to $20^{\text {th }}$ day). They served as curative groups at two doses of 150 and $300 \mathrm{mg} / \mathrm{kg}$, respectively, and sacrificed on the $21^{\text {st }}$ day.

- Group VII: Rats were treated with $300 \mathrm{mg} / \mathrm{kg}$ of EBML for 15 days and sacrificed on the $16^{\text {th }}$ day, served as EBML control group [13].

\section{Collection of urine for cisplatin-treated rats}

After completion of the treatment schedule, the rats (Groups I-VII) were kept in metabolic cages for $24 \mathrm{~h}$ for urine collection. The urine collected was measured in volume ( $\mathrm{Vol}, \mathrm{ml} / 24 \mathrm{~h})$ and was used to calculate creatinine clearance $(\mathrm{Cr} \mathrm{Cl})$. $\mathrm{Cr} \mathrm{Cl}$ is expressed as $\mathrm{ml} / \mathrm{hr}$ and estimated using the following formula:

\section{$\mathrm{CrCl}=[$ Urine $\mathrm{Cr} .(\mathrm{mg} / \mathrm{dl}) \times$ Urine vol. $(\mathrm{ml} / \mathrm{h})] /[\mathrm{S} . \mathrm{Cr} .(\mathrm{mg} / \mathrm{dl})] \times 100$}

\section{Treatment schedule to evaluate DOX-induced cardiotoxicity} Animals were divided into seven groups $(\mathrm{n}=8)$

- Group I: Rats were administered with 1\% CMC (p.o) once daily for 15 days and sacrificed on the $16^{\text {th }}$ day, served as normal.

- Group II: Rats received a single dose of DOX (15 mg/kg, i.p) to induce cardiotoxicity on the day 1 and sacrificed on the $4^{\text {th }}$ day, served as DOX disease control.

- Groups III and IV: Rats were treated with EBML $150 \mathrm{mg} / \mathrm{kg}$ and
$300 \mathrm{mg} / \mathrm{kg}$ for 15 days. On the $16^{\text {th }}$ day, rats were administered with a single dose of DOX (15 mg/kg, i.p) and sacrificed on the $19^{\text {th }}$ day, served as prophylactic groups at two doses of 150 and $300 \mathrm{mg} / \mathrm{kg}$, respectively.

- Groups V and VI: Rats were administered with single dose of DOX (15 mg/kg, i.p) on the $1^{\text {st }}$ day and then treated with EBML $150 \mathrm{mg} / \mathrm{kg}$ and $300 \mathrm{mg} / \mathrm{kg}$ for 15 days (i.e., $4^{\text {th }}-18^{\text {th }}$ day) and were sacrificed on the $19^{\text {th }}$ day, served as curative groups at two doses 150 and $300 \mathrm{mg} / \mathrm{kg}$, respectively.

- Group VII: Rats were treated with $300 \mathrm{mg} / \mathrm{kg}$ of EBML for 15 days and sacrificed on the $16^{\text {th }}$ day, served as EBML control group [14].

\section{Calculation of percentage change in body weight (wt)}

Individual wt of rats was recorded on the day 1 and at the end of the treatment schedule before sacrificing the animal. Percentage change in body wt was calculated using the following formula:

$\%$ change in body wt $=($ Initial body wt-Final body wt $) /$ Final body $w t) \times 100$

\section{Collection of blood}

Blood was collected by retro-orbital puncture before sacrificing the rats and allowed to clot for $20 \mathrm{~min}$. It was then centrifuged in a cooling centrifuge at $3000 \mathrm{~g}$ for $10 \mathrm{~min}$ at $4^{\circ} \mathrm{C}$ initially and later at $5000 \mathrm{~g}$ for $10 \mathrm{~min}$. The supernatant serum obtained was collected and stored at $-20^{\circ} \mathrm{C}$ until used for the estimation of serum parameters of kidney and heart using biochemical kits by recording the values using semi-auto analyzer (Inkarp ES-100).

Biochemical parameters of the kidney and heart to be evaluated The serum parameters used to evaluate nephroprotective activity include serum creatinine (S.Cr, mg/dl), total protein $(\mathrm{g} / \mathrm{dl})$, serum urea (S. urea, $\mathrm{mg} / \mathrm{dl}$ ), serum uric acid (S. uric acid, $\mathrm{mg} / \mathrm{dl}$ ), and blood urea nitrogen (BUN mg/dl).

The serum parameters used to assess cardioprotective activity are creatine kinase-myocardium (CK-MB, IU/L), lactate dehydrogenase (LDH, IU/L), (TG, mg/dl), (CH, mg/dl), low-density lipoproteins (LDLs, $\mathrm{mg} / \mathrm{dl}$ ), and high-density lipoproteins (HDLs, $\mathrm{mg} / \mathrm{dl}$ ). After collection of blood, rats were sacrificed by cervical dislocation method. Kidney and heart tissues were rapidly excised, trimmed of connective tissue, and washed with ice-cold normal saline, and wet wt was noted to calculate organ wt (mg/100 g).

Quantification of phytochemical constituents of the plant extracts Total flavonoid content was determined according to a modified colorimetric method [15] and the amount of total phenol was determined according to the Folin-Ciocalteu procedure [16].

\section{Antioxidant ability assays}

ABTS radical scavenging activity $[17,18]$, DPPH radical scavenging assay [19], metal chelating assay [20], total antioxidant activity [21], and reducing power assay [22] were done to know the potential of antioxidant activity of the plant extracts.

\section{In vivo antioxidant studies}

$10 \%$ post-mitochondrial supernatant was prepared according to Naveen et al. [23] for the assay of in vivo antioxidants such as malondialdehyde (MDA) content [24], reduced glutathione (GSH) [25], and catalase (CAT) [26].

\section{Assay of cardiac ATPases}

The heart tissues were washed with ice-cold $0.9 \%$ saline, and homogenate was prepared in $0.1 \mathrm{~N}$ Tris-hydrochloric acid buffer $(\mathrm{pH}$ 7.4). Tissue homogenate pellet obtained after centrifugation was resuspended in ice-cold Tris buffer $(10 \mathrm{mM}, \mathrm{pH} 7.4)$ to get a final concentration of $10 \%$ and was used for the estimation of $\mathrm{Na}^{+} \mathrm{K}^{+}$ ATPase [27], $\mathrm{Ca}^{+2}$ ATPase [28], and $\mathrm{Mg}^{+2}$ ATPase [29]. 
Statistical analysis

All the results were expressed as mean \pm standard error of mean. Data obtained from various groups were subjected to one-way analysis of variance followed by Tukey's multiple comparison test. Significant values were set at $\mathrm{p}<0.05$.

\section{RESULTS}

Phytochemical screening of EBML revealed the presence of alkaloids, glycosides, flavonoids, phenols, and saponins. Total flavonoid content expressed as $\mu \mathrm{g} / \mathrm{mg}$ of quercetin equivalents and total phenol content expressed as $\mu \mathrm{g} / \mathrm{mg}$ of gallic acid equivalents was tested for solvents pet ether, chloroform, ethyl acetate and ethanol of B. malabarica. The quercetin euivalents and gallic acid euivalents were found to be higher in the ethanolic extract than the other extracts pet ether, choloroform and ethyl acetate B. malabarica (Table 1).

The EBML exhibited higher free radical scavenging and reducing power among all the extracts studied in different in vitro models (Table 2).

Group II rats of cisplatin treatment group showed a significant decrease in percentage change in body wt, urine volume, and $\mathrm{Cr} \mathrm{Cl}$ and a significant increase in the kidney wt when compared to Group I. Treatment with EBML prophylactically and curatively has significantly increased the body wt, urine volume, and $\mathrm{Cr} \mathrm{Cl}$. and significantly decreased kidney wt when compared to Group II (Table 3)

Animals treated with cisplatin in Group II showed a significant increase in S.Cr, total protein, S. urea, S. uric acid, and BUN levels when compared to normal group. Treatment Groups III to VI treated with EBML have shown a significant decrease in S.Cr, total protein, S. urea, S. uric acid, and BUN levels when compared to Group II (Table 4).

A significant increase in MDA and a significant decrease in reduced GSH and CAT enzymes were observed in Group II rats treated with cisplatin on comparison with Group I. MDA levels were significantly decreased with increase of GSH and CAT in the treatment Groups III, IV, V, and VI on comparison with Group II (Table 5).

A significant decrease in \% change in body wt and HDL and a significant increase in heart wt, CK-MB, LDH, CH, and TG levels were observed in DOX-treated Group II rats when compared with Group I rats. Treatment with EBML has significantly increased the HDL levels and significantly

Table 1: Quantification of phytochemical constituents of BML

\begin{tabular}{lll}
\hline \multirow{2}{*}{ Extracts } & \multicolumn{2}{l}{ Quantification of phytochemical constituents } \\
\cline { 2 - 3 } & Total flavonoid & Total phenol \\
\cline { 2 - 3 } & $\boldsymbol{\mu} \mathbf{g} / \mathbf{m g ~ Q E} \pm$ SEM & $\boldsymbol{\mu g} / \mathbf{m g ~ G A E} \pm$ SEM \\
\hline Ethanol & $311.7 \pm 03.33$ & $165.0 \pm 04.33$ \\
EAF & $228.3 \pm 03.33$ & $154.2 \pm 01.67$ \\
ChF & $225.0 \pm 10.89$ & $132.5 \pm 01.25$ \\
Pet ether & $106.7 \pm 07.95$ & $108.3 \pm 02.21$ \\
\hline
\end{tabular}

EAF: Ethyl acetate fraction, ChF: Chloroform fraction, QE: Quercetin equivalents, GAE: Gallic acid equivalents, BML: Bassia malabarica leaves, SEM: Standard error of mean decreased the $\mathrm{CK}-\mathrm{MB}, \mathrm{LDH}, \mathrm{CH}$, and TG levels on comparison with Group II (Table 6).

A significant decrease in cardiac ATPases such as $\mathrm{Na}^{+} \mathrm{K}^{+}$ATPase and $\mathrm{Mg}^{2+}$ ATPase and a significant increase in $\mathrm{Ca}^{2+}$ ATPase were seen in Group II when compared to Group I. On treatment with EBML in Groups III-VI, a significant increase in $\mathrm{Na}^{+} \mathrm{K}^{+}$ATPase and a significant decrease in $\mathrm{Ca}^{2+}$ ATPase levels were observed on comparison with Group II (Table 7).

Group II rats treated with DOX showed a significant increase in MDA and a significant decrease in reduced GSH and CAT levels on comparison with Group I. Animals treated with EBML prophylactically and curatively in Groups III-VI have shown a significant decrease in MDA content with a simultaneous decrease in reduced GSH levels when compared to Group II (Table 8).

\section{DISCUSSION}

Many plants contain antioxidant compounds, and these compounds protect cells against the damaging effects of reactive oxygen species (ROS) [30]. Therefore, the study of plants as a resource of medicine has become more important in the context of present global trade scenario where oxidative stress is found to be one of the major causes of health hazards [31].

A significant reduction in the percentage change in body wt in disease control groups may be due to gastrointestinal toxicity and concomitant loss of the animal appetite with subsequent reduction of food ingestion [32]. Infiltration of the organs, tissue damage, and reduction in their functions lead to increase in organ wt (kidney and heart) in disease control groups (Group II) [33].

Decrease in urine volume and $\mathrm{Cr} \mathrm{Cl}$ in cisplatin disease control group is due to decrease in renal blood flow and glomerular filtration rate which occurs within $3 \mathrm{~h}$ after cisplatin infusion [34]. Glomerular damage as a result of ROS generation increased the levels of S.Cr, total protein, S. urea, S. uric acid, and BUN in Group II $[35,36]$. Treatment with EBML increased the urine volume and $\mathrm{Cr} \mathrm{Cl}$ with simultaneous decrease of S.Cr, total protein, S. urea, S. uric acid, and BUN levels proving the protective activity of the plant.

CK-MB and LDH are the cardiac enzymes primarily found in the MB used to evaluate the existence and extent of myocytes injury [37]. DOX disease control group rats increased these biomarkers in the extracellular fluid due to an increased leakage of these enzymes from mitochondria as a result of toxicity induced by DOX [38]. Administration of DOX interferes with the metabolism or biosynthesis of lipids increasing the plasma levels of TG, $\mathrm{CH}$, and LDL in Group II rats of DOX. Whereas, treatment with EBML might decrease the interference with the metabolism and thus decrease the plasma levels of TG, CH, and LDL $[39,40]$

Administration of DOX showed peroxidation of membrane lipids which inactivated $\mathrm{Na}^{+} \mathrm{K}^{+}$ATPase and $\mathrm{Ca}^{2+}$ ATPase. Decreased activity of $\mathrm{Ca}^{2+}$ ATPase increased intracellular concentration of free calcium and altered the signal transduction pathways and cellular fluidity [41].

Table 2: Effect of B. malabarica extracts on in vitro antioxidant parameters

\begin{tabular}{|c|c|c|c|c|c|}
\hline \multirow[t]{3}{*}{ Extracts } & ABTS & DPPH & MC assay & Total AO activity & \multirow[t]{2}{*}{ RPA } \\
\hline & $\mathrm{IC}_{50} \pm \mathrm{SEM}$ & $\mathrm{IC}_{50} \pm \mathrm{SEM}$ & $\mathrm{IC}_{50} \pm \mathrm{SEM}$ & $\mathrm{IC}_{50} \pm \mathrm{SEM}$ & \\
\hline & Vit C IC ${ }_{50}=30.31$ & Vit C IC ${ }_{50}=15.33$ & EDTA IC $_{50}=\mathbf{2 8 . 2 4}$ & Vit C IC ${ }_{50}=52.94$ & $\mu \mathrm{g} / \mathrm{mg}$ of $\mathrm{AAE} \pm \mathrm{SEM}$ \\
\hline Ethanol & $36.50 \pm 01.10$ & $21.33 \pm 01.60$ & $29.87 \pm 01.68$ & $57.14 \pm 04.41$ & $70.83 \pm 01.64$ \\
\hline EAF & $57.54 \pm 03.98$ & $53.33 \pm 02.46$ & $41.42 \pm 02.82$ & $76.82 \pm 02.50$ & $54.33 \pm 01.36$ \\
\hline $\mathrm{ChF}$ & $45.12 \pm 03.55$ & $38.51 \pm 02.45$ & $31.24 \pm 01.19$ & $67.91 \pm 07.22$ & $66.17 \pm 01.17$ \\
\hline Petroleum ether & $59.83 \pm 03.69$ & $69.45 \pm 03.98$ & $59.46 \pm 03.39$ & $82.08 \pm 07.22$ & $42.67 \pm 01.30$ \\
\hline
\end{tabular}

$\mathrm{IC}_{50}$ : Half maximal inhibitory concentration, Vit C: Vitamin C, AO: Antioxidant, MC assay: Metal chelation assay, AAE: Ascorbic acid equivalents, RPA: Reducing power assay. B. malabarica: Bassia malabarica, EAF: Ethyl acetate fraction, ChF: Chloroform fraction, SEM: Standard error of mean, DPPH: 1, 1-diphenyl-2-picrylhydrazyl 
Table 3: Effect of ethanolic extract of B. malabarica on body wt and urinary parameters

\begin{tabular}{llll}
\hline Groups & \% change in body wt & Kidney wt (mg/100 g) & Urinary parameters \\
\cline { 3 - 4 } & & & Urine Volume (ml/24 h) \\
\hline I & $08.61 \pm 0.68$ & $233.8 \pm 11.52$ & $08.35 \pm 0.41$ \\
II & $-15.08 \pm 1.67^{\wedge}$ & $458.0 \pm 10.15^{\wedge}$ & $01.79 \pm 0.34^{\wedge}$ \\
III & $-04.82 \pm 0.83^{*}$ & $307.8 \pm 08.04^{*}$ & $06.44 \pm 0.30^{*}$ \\
IV & $02.38 \pm 0.91^{*}$ & $253.3 \pm 13.10^{*}$ & $08.06 \pm 0.35^{*}$ \\
V & $-11.96 \pm 1.67$ & $418.5 \pm 13.55$ & $03.10 \pm 0.31$ \\
VI & $-09.68 \pm 0.86^{*}$ & $400.5 \pm 10.65^{*}$ & $0.24 \pm 0.06^{\wedge}$ \\
VII & $07.86 \pm 0.67$ & $246.2 \pm 12.45$ & $01.19 \pm 0.24$ \\
\hline
\end{tabular}

Values are expressed as mean \pm SEM and $\mathrm{n}=8, \wedge \mathrm{p}<0.05$ when compared to Group I, ${ }^{\mathrm{p}} \mathrm{p}<0.05$ when compared to Group II. B. malabarica: Bassia malabarica, SEM: Standard error of mean, wt: Weight

Table 4: Effect of ethanolic extract of $B$. malabarica on serum parameters

\begin{tabular}{lllll}
\hline Groups & S.Cr. $(\mathbf{m g} / \mathbf{d l})$ & Total protein $(\mathrm{g} / \mathbf{d l})$ & S. urea $(\mathbf{m g} / \mathbf{d l})$ & S. uric acid (mg/dl) \\
\hline I & $0.23 \pm 0.04$ & $5.44 \pm 0.21$ & $12.64 \pm 1.08$ & $3.44 \pm 0.42$ \\
II & $0.98 \pm 0.08^{\wedge}$ & $8.97 \pm 0.22^{\wedge}$ & $49.50 \pm 3.95^{\wedge}$ & $8.20 \pm 0.49^{\wedge}$ \\
III & $0.43 \pm 0.05^{*}$ & $6.89 \pm 0.38^{*}$ & $27.10 \pm 1.39^{*}$ & $5.34 \pm 0.39^{*}$ \\
IV & $0.36 \pm 0.04^{*}$ & $6.58 \pm 0.53^{*}$ & $15.62 \pm 1.09^{*}$ & $4.41 \pm 0.24^{*}$ \\
V & $0.61 \pm 0.04^{*}$ & $8.68 \pm 0.76$ & $39.98 \pm \pm 1.82^{*}$ & $7.11 \pm 0.46^{*}$ \\
VI & $0.50 \pm 0.05^{*}$ & $7.86 \pm 0.56$ & $29.16 \pm 1.53^{*}$ & 6.50 \\
VII & $0.27 \pm 0.04$ & $5.57 \pm 0.56$ & $14.02 \pm 1.19$ & $0.68 \pm 0.34^{*}$ \\
\hline
\end{tabular}

Values are expressed as mean \pm SEM and $\mathrm{n}=8,{ }^{\wedge} \mathrm{p}<0.05$ when compared to Group I, ${ }^{*} \mathrm{p}<0.05$ when compared to Group II. . malabarica: Bassia malabarica,

SEM: Standard error of mean, S. urea: Serum urea, S. uric: Serum uric

Table 5: Effect of ethanolic extract of B. malabarica on in vivo antioxidant parameters

\begin{tabular}{llll}
\hline Groups & MDA (nM/g tissue) & GSH (nM/g tissue) \\
\hline I & $01.31 \pm 0.14$ & $45.99 \pm 2.80$ & CAT (K/g Pr) \\
II & $13.85 \pm 1.64^{\wedge}$ & $06.87 \pm 1.28^{\wedge}$ & $223.4 \pm 6.28$ \\
III & $04.23 \pm 0.45^{*}$ & $23.68 \pm 1.65^{*}$ & $67.14 \pm 5.06^{\wedge}$ \\
IV & $02.53 \pm 0.20^{*}$ & $35.06 \pm 2.92^{*}$ & $157.6 \pm 6.10^{*}$ \\
V & $06.68 \pm 0.29^{*}$ & $05.91 \pm 1.55$ & $181.0 \pm 7.74^{*}$ \\
VI & $06.23 \pm 0.33^{*}$ & $16.72 \pm 1.96$ & $93.57 \pm 5.79^{*}$ \\
VII & $01.33 \pm 0.19$ & $45.50 \pm 4.25$ & $127.4 \pm 7.22^{*}$ \\
\hline
\end{tabular}

Values are expressed as mean \pm SEM and $n=8,{ }^{\wedge} p<0.05$ when compared to Group I, *p $<0.05$ when compared to Group II. GSH: Glutathione, MDA: Malondialdehyde, CAT: Catalase, SEM: Standard error of mean, B. malabarica: Bassia malabarica

Table 6: Effect of ethanolic extract of B. malabarica on body wt, heart wt, and serum parameters

\begin{tabular}{|c|c|c|c|c|c|c|c|}
\hline Group & $\%$ change in body wt & Heart wt (mg/100 g) & CK-MB (IU/L) & LDH (IU/L) & $\mathrm{CH}$ mg/dl & TG mg/dl & HDL mg/dl \\
\hline I & $08.31 \pm 0.88$ & $199.0 \pm 14.64$ & $17.02 \pm 01.71$ & $396.7 \pm 19.44$ & $76.0 \pm 6.04$ & $63.71 \pm 3.62$ & $34.72 \pm 1.78$ \\
\hline II & $-15.41 \pm 1.62^{\wedge}$ & $448.0 \pm 22.97^{\wedge}$ & $47.01 \pm 01.65^{\wedge}$ & $738.3 \pm 18.29^{\wedge}$ & $199.8 \pm 5.96^{\wedge}$ & $165.0 \pm 7.27^{\wedge}$ & $25.87 \pm 1.61^{\wedge}$ \\
\hline III & $-07.65 \pm 0.83^{*}$ & $276.8 \pm 11.79^{*}$ & $29.54 \pm 01.94^{*}$ & $577.8 \pm 23.73^{*}$ & $140.2 \pm 7.01^{*}$ & $117.1 \pm 5.35^{*}$ & $28.30 \pm 1.42$ \\
\hline IV & $02.09 \pm 1.07^{*}$ & $219.7 \pm 10.83^{*}$ & $25.03 \pm 01.77^{*}$ & $535.3 \pm 18.36^{*}$ & $115.4 \pm 5.72^{*}$ & $101.6 \pm 4.14^{*}$ & $33.85 \pm 1.35^{*}$ \\
\hline $\mathrm{V}$ & $-11.81 \pm 1.03$ & $395.0 \pm 08.97$ & $36.39 \pm 01.40$ & $683.0 \pm 22.13$ & $189.8 \pm 5.77^{*}$ & $143.9 \pm 2.92^{*}$ & $26.00 \pm 1.37$ \\
\hline VI & $-09.81 \pm 0.62^{*}$ & $389.2 \pm 09.56^{*}$ & $31.10 \pm 02.09^{*}$ & $603.7 \pm 19.19^{*}$ & $163.7 \pm 5.85^{*}$ & $125.2 \pm 4.58^{*}$ & $26.61 \pm 1.33$ \\
\hline VII & $07.71 \pm 0.54$ & $205.2 \pm 08.82$ & $17.17 \pm 01.57$ & $425.2 \pm 13.35$ & $63.87 \pm 4.78$ & $59.30 \pm 4.61$ & $36.79 \pm 1.64$ \\
\hline
\end{tabular}

Values are expressed as mean \pm SEM and $n=8,{ }^{\wedge} \mathrm{p}<0.05$ when compared to Group I, ${ }^{\mathrm{p}} \mathrm{p}<0.05$ when compared to Group II. CK-MB: Creatine kinase-myocardium, LDH: Lactate dehydrogenase, CH: Cholesterol, TG: Triglyceride, HDL: High-density lipoprotein, B. malabarica: Bassia malabarica, SEM: Standard error of mean

Table 7: Effect of ethanolic extract of B. malabarica on in vivo antioxidant parameters

\begin{tabular}{llll}
\hline Groups & MDA (nM/g tissue) & GSH (nM/g tissue) & CAT (K/g Pr) \\
\hline I & $03.28 \pm 0.40$ & $12.14 \pm 1.10$ & $74.14 \pm 6.98$ \\
II & $14.27 \pm 1.03^{\wedge}$ & $5.64 \pm 0.56^{\wedge}$ & $9.86 \pm 3.34^{\wedge}$ \\
III & $04.85 \pm 0.43^{*}$ & $11.13 \pm 1.11^{*}$ & $51.00 \pm 3.53^{*}$ \\
IV & $03.65 \pm 0.39^{*}$ & $11.63 \pm 1.09^{*}$ & $69.29 \pm 3.34^{*}$ \\
V & $11.51 \pm 0.46^{*}$ & $09.08 \pm 1.56$ & $17.00 \pm 2.66$ \\
VI & $09.21 \pm 0.48^{*}$ & $09.57 \pm 1.28$ & $26.86 \pm 3.61$ \\
VII & $02.80 \pm 0.40$ & $14.19 \pm 1.31$ & $76.43 \pm 5.33$ \\
\hline
\end{tabular}

Values are expressed as mean \pm SEM and $\mathrm{n}=8,{ }^{\wedge} \mathrm{p}<0.05$ when compared to Group I, ${ }^{*} \mathrm{p}<0.05$ when compared to Group II. GSH: Glutathione, MDA: Malondialdehyde, CAT: Catalase, SEM: Standard error of mean, B. malabarica: Bassia malabarica 
Table 8: Effect of ethanolic extract of B. malabarica on cardiac ATPases

\begin{tabular}{llll}
\hline Groups & Na $^{+} \mathbf{K}^{+}$ATPase units* & Ca $^{* 2}$ ATPase units $^{*}$ & Mg $^{+2}$ ATPase units* $^{*}$ \\
\hline I & $4.037 \pm 0.136$ & $1.841 \pm 0.116$ & $0.336 \pm 0.011$ \\
II & $2.877 \pm 0.104^{\wedge}$ & $3.823 \pm 0.116^{\wedge}$ & $0.132 \pm 0.011^{\wedge}$ \\
III & $3.541 \pm 0.140^{*}$ & $2.210 \pm 0.155^{*}$ & $0.249 \pm 0.013^{*}$ \\
IV & $4.027 \pm 0.121^{*}$ & $1.960 \pm 0.173^{*}$ & $0.300 \pm 0.012^{*}$ \\
V & $3.253 \pm 0.130$ & $2.567 \pm 0.106^{*}$ & $0.181 \pm 0.013$ \\
VI & $3.404 \pm 0.171$ & $2.343 \pm 0.154^{*}$ & $0.220 \pm 0.013^{*}$ \\
VII & $4.053 \pm 0.142$ & $1.793 \pm 0.127$ & $0.341 \pm 0.013$ \\
\hline
\end{tabular}

Values are expressed as mean \pm SEM and $n=8,{ }^{\wedge} \mathrm{p}<0.05$ when compared to Group I, ${ }^{*} P<0.05$ when compared to Group II, Units*: Milli mol of phosphorus liberated/ $\mathrm{min} / \mathrm{mg}$ of protein. ATP: Adenosine triphosphate, SEM: Standard error of mean, B. malabarica: Bassia malabarica

Treatment with EBML might have decreased the concentration of free calcium and thus increased the levels of $\mathrm{Na}^{+} \mathrm{K}^{+}$ATPase and decreased the levels of $\mathrm{Ca}^{2+}$ ATPase.

Cisplatin (cis-diamminedichloroplatinum II) is a potent antineoplastic drug used in the treatment of solid tumors. The main dose-limiting side effect of cisplatin is nephrotoxicity [42-44]. Cisplatin generates ROS which inhibits the activity of antioxidant enzymes in renal tissues with increased lipid peroxidation and nephrotoxicity $[45,46]$. DOX is a naturally occurring anthracycline that is widely used in the treatment of a variety of hematological and solid malignancies such as leukemia, bladder, lung, and breast cancers [47]. Its clinical uses are often limited by the dose-dependent cardiotoxicity which leads to cardiomyopathy and eventually congestive heart failure [48]. Oxidative stress-generating ROS is the cornerstone of DOX-induced cardiotoxicity [49].

ROS generated on the administration of cisplatin and DOX in Group II rats caused peroxidation of lipids with a concomitant decline in the level of GSH. Inhibition in the activities of antioxidant enzymes leads to the generation of superoxide anion $\left(\mathrm{O}^{2-}\right)$ and hydrogen peroxide $\left(\mathrm{H}_{2} \mathrm{O}_{2}\right)$, which in turn formed hydroxyl radical $(\mathrm{OH}$.) and brought about a number of reactions harmful to structural and functional integrity [50].

Yogesh et al. reported that the presence of tannin (phenol) and flavonoids in the plant extract has antioxidant activity [51]. Thus, the administration of EBML having flavonoid and phenolic constituents might have augmented reduced GSH and antioxidant enzyme levels and scavenges lipid peroxides [52-54].

\section{CONCLUSION}

The results of the present study revealed the protective effect of EBML against cisplatin-induced nephrotoxicity and DOX-induced cardiotoxicity. The presence of phytochemical constituents might be responsible for a protective effect against free radicals generated by the administration of cisplatin and DOX.

\section{ACKNOWLEDGMENT}

The authors are thankful to University Grants Commission (UGC) for providing financial assistance through UGC-SAP-DRS-I program to the Institute of Pharmaceutical Technology (IPT), Sri Padmavati Mahila Visvavidyalayam (Women's University), Tirupati.

\section{AUTHORS' CONTRIBUTION}

Conceived and designed the experiments: KVSRG Prasad, Sujatha, and Sushma. Performed the experiment: Sushma. Analyzed data: Sushma and Sujatha. All authors read and approved the final manuscript.

\section{CONFLICTS OF INTEREST}

The authors have no conflicts of interest.

\section{REFERENCES}

1. Noor MR, Hseon TE, Jeffrey LJ. Gynaecologic Cancer: A Handbook for Students and Practitioners. World Cancer Statistics and Burden of
Gynaecological Cancer. U.S, Norway: Panstanford, Taylor and Francis group Publishers; 2014. p. 2.

2. Parekh J, Jadeja D, Chanda S. Efficacy of aqueous and methanol extracts of some medicinal plants for potential antibacterial activity. Turk J Biol 2005;29:203-10.

3. Khare CP. Indian Medicinal Plants: An Illustrated Dictionary. Berlin, Heidelberg: Springer-Verlag Publishers; 2007. p. 392.

4. Awasthi YC, Bhatnagar SC, Mitra CR. Chemurgy of sapotaceous plants: Madhuca species of India. Econ Bot 1975;29:380-9.

5. Kirtikar KR, Basu BD. Indian Medicinal Plants. Vol. 2. Allahabad, India: Basu LM Publishers; 1935. p. 1536.

6. Mali RR, Ashok K, Kuar SA, Amitabh T. Formulation of herbal shampoos from Asparagus Racemosus, Acacia Concin, Sapindus mukorossi. Int J Pharm Sci Rev Res 2010;4:39-44.

7. Nadkarni KM. Indian Materia Medica. $3^{\text {rd }}$ ed., Vol. 1. Mumbai: Popular Prakashan Private Limited Publishers; 2007. p. 950.

8. Vardana R. Floristic Plants of the World. $1^{\text {st }}$ ed., Vol. 2. New Delhi: Sarup and Sons Publishers; 2006. p. 519.

9. Sushma M, Prasad KV, Laxmi Bai DJ, Chidrawar VR, Rao UM. Prophylactic and curative effect of ethanolic extract of Bassia malabarica bark against cisplatin induced nephrotoxicity. Asian J Pharm Clin Res 2014; 7:143-6.

10. Seneviratne KN, Kotuwegedara RT, Ekanayake S. Serum cholesterol and triglyceride levels of rats fed with customer selected coconut oil blends. Int Food Res J 2011;18:1303-8.

11. Deshmukh MA, Theng MA. Phytochemical screening, quantitative analysis of primary and secondary metabolites of Acacia arabica bark. Int J Curr Pharm Res 2018;10:35-7.

12. OECD Guidelines for Testing of Chemicals. Acute Oral Toxicity-Acute Toxic Class Method. OECD; 2001. p. 1-14.

13. El Awady EE, Moustafa YM, Abo-Elmatty DM, Radwan A. Cisplatin induced cardiotoxicity: Mechnaisms and cardioprotective strategies. Eur J Pharmacol 2011;650:335-41.

14. Singh MK, Mohd F, Ayaz A, Ankur S, Jyothi Y. Protective effect of Lagenaria siceraria against doxorubicin induced cardiotoxicity in Wistar rats. Int J Drug Dev Res 2012;4:298-305.

15. Bao J, Cay Y, Sun M, Warg G, Corke H. Anthocyanins, flavonol and free radical scavenging activity of Chinese bayberry (Myrica rubra) extracts and their colour properties and stability. J Agric Food Chem 2005;53:2327-32.

16. Singleton VL, Rossi JA. Colorimetry of total phenolics with phosphor molybdic phosphotungstic acid reagents. Am J Enol Viticult 1965; $16: 144-58$.

17. Re R, Pellegrini N, Proteggente A, Pannala A, Yang M, Rice-Evans C. Anti-oxidant activity applying an improved ABTS radical cation decolourization assay. Free Radical Biol Med 1999;26:1231-7.

18. Manda H, Rao BK, Yashwant, Kutty GN, Swarnkar SK, et al.Antioxidant, anti-inflammatory and antipyretic activities of ethyl acetate fraction of ethanolic extract of Schrebera swietenioides Roxb. Root. Int J Toxicol Pharmacol Res 2009;1:7-11.

19. Blois MS. Anti-oxidant determinations by the use of a stable free radical. Nature 1958;29:1199-2000.

20. Eric D, Welch B. Role of ferritin as a lipid oxidation catalyst in muscle food. J Agric Food Chem 1990;38:674-7.

21. Prieto P, Pineda M, Aiguel M. Spectrophotometer quantification of anti-oxidant capacity through the formation of phosphomolybdenum complex: Specific application to the determination of vitamin E. Anal Biochem 1999;269:337-41

22. Ferreira CF, Baptista P, Vilas-Boas M, Barros L. Free radical scavenging capacity and reducing power of wild edible mushrooms from northeast Portugal: Individual cap and stipe activity. Food Chem 
2007:100:1511-6.

23. Tirkey N, Sangeeta P, Anurag K, Chopra K. Hesperidine, a citrus bioflavonoid, decreases the oxidative stress produced by carbon tetra chloride in rat liver and kidney. BMC Pharmacol 2005;5:1-8.

24. Niehaus WG, Samuelsson B. Formation of malondialdehyde from phospholipids arachidonate during microsomal lipid peroxidation. Euro J Biochem 1968;6:126-30.

25. Jollow D, Mitchell L, Zampaglione N, Gillete J. Bromobenzene induced liver necrosis: Protective role of glutathione and evidence for 3, 4-bromobenzenoxide as the hepatotoxic intermediate. Pharmacology 1984;11:151-69.

26. Hugo EB. Oxidoreductases acting on groups other than $\mathrm{CHOH}$ : Catalase. In: Colowick SP, Kalpan NO, Packer L, editors. Methods in Enzymology. Vol. 105. London: Academic Press; 1984. p. 121-5.

27. Bonting SL. Sodium-potassium activated adenosine triphosphate and cation transport. In: Bittar EE, editor. Membranes and Transport. Vol. 1. London, New York, Sydney, Toronto: Wiley- Interscience; 1970. p. 257-363.

28. Hjerken S, Pan H. Purification and characterization of two form of low affinity calcium ion ATPase from erythrocyte membrane. Biochim Biphys Acta 1983;8:281-728.

29. Ohinish T, Suzuki T, Suzuki Y, Ozawa K. A comparative study of plasma membrane $\mathrm{Mg}^{2+}$ ATPase activities in normal, regenerating and malignant cells. Biochim Biphys Acta 1982;684:67-74.

30. Dasgupta N, Bratati De. Antioxidant activity of some leafy vegetables of India: A comparative study. J Food Chem 2006;10:417-74.

31. Padmaja M, Sravanthi M, Hemalatha KP. Evaluation of antioxidant activity of two Indian medicinal plants. J Phytol 2011;3:86-91.

32. Atessahin A, Yilmaz S, Karahan I, Ceribasi AO, Karaoglu A. Effects of lycopene against cisplatin induced nephrotoxicity and oxidative stress in rats. Toxicology 2005;212:116-23.

33. Hae-Ran P, Eun-Jin J, Sung-Kee J, Uhee J, Sung-Ho K, Sung-Tae Y. Enhanced antitumor efficacy of cisplatin in combination with HemoHIM in tumor-bearing mice. BMC Cancer 2009;9:85.

34. Cornelison TL, Reed E. Nephrotoxicity and hydration management for cisplatin, carboplatin and ormaplatin. Gynecol Oncol 1993;50:147-58.

35. Mansour MA, Mostafa AM, Nagi MN, Khattab MM, Al-Shabanah OA. Protective effect of aminoguanidine against nephrotoxicity induced by cisplatin in normal rats. Comparative Biochem Physiol C Toxicol Pharmacol 2002;132:123-8.

36. Sueishi K, Mishima K, Makino K, Itoh Y, Tsuruya K, Hi-Rakata H, et al. Protection by radical scavenger edaravone against cisplatin induced nephrotoxicity in rats. Euro J Pharmacol 2002;451:203-8.

37. Singh G, Singh AT, Abraham A. Protective effect of Terminalia arjuna against doxorubicin induced cardiotoxicity. J Ethnopharmacol 2008;117:123-9.

38. Varadharajana R, Rajalingama D, Palanic S. GC MS/MS Analysis and cardioprotective potential of Cucumis callosus on doxorubicin induced cardiotoxicity in rats. Int J Pharm Pharm Sci 2016;8:239-45.

39. Koti BC, Vishwanathswamy AH, Wagawade J, Thippeswamy AH. Cardioprotective effect of lipistat against doxorubicin induced myocardial toxicity in albino rats. Indian J Exp Biol 2009;47:41-6.

40. Ragavendran P, Sophia D, Arrulraj C, Gopalakrishnan VK. Cardioprotective effect of aqueous, ethanol and aqueous ethanol extract of Aerva lanata (Linn.) against doxorubicin induced cardiomyopathy in rats. Asian Pac J Trop Biomed 2012;2012:S212-8.

41. Levy J, Gavin JR, Hammerman MR, Aviol LV. $\mathrm{Ca}^{2+}$ ATPase, $\mathrm{Mg}^{2+}$ ATPase activity in kidney baso lateral membrane in non-insulin dependent diabetic rats: Effect of insulin. Diabetes 1986;35:899-905.

42. Sastry J, Kellie SJ. Severe neurotoxicity, ototoxicity and nephrotoxicity following high-dose cisplatin and amifostine. Pediatr Hematol Oncol 2005;22:441-5.

43. Arany I, Safirstein RL. Cisplatin nephrotoxicity. Semin Nephrol 2003;23:460-4.

44. Boulikas T. Poly (ADP-ribose) synthesis in blocked and damaged cells and its relation to carcinogens. Anticancer Res 1992;12:885-98.

45. An Y, Xin H, Yan W, Zhou X. Amelioration of cisplatin induced nephrotoxicity by pravastatin in mice. Exper Toxicol Pathol 2011;63:215-9.

46. Daisy P, Suveena S. A review on comprehensive cancer pathways. Int J Appl Pharm 2014;6:1-5

47. Karim S, Bhandari U, Kumar H, Salam A, Siddiqui MA, Pillai KK. Doxorubicin induced cardiotoxicity and its modulation by drugs. Indian J Pharmacol 2001;33:203-7.

48. Lefrak EA, Pitha J, Rosenheim S, Gottlieb T. A clinicopathologic analysis of adiramycin cardiotoxicity. Cancer 1973;32:302-14

49. Ravichandra V, Hanumantharayappa B, Reddy Papasani VM. Evaluation of cardio protective activity of galangin against doxorubicin induced cardiomyopathy. Int J Pharm Pharm Sci 2014;6:86-90.

50. Davey MS,Atlee CW. Inotropic and cardioprotective effect of Terminalia paniculata Roth extract in doxorubicin induced cardiotoxicity in rats. Int J Res Ayurveda Pharm 2011;2:869-75

51. Yogesh CY, Srivastav DN, Seth AK, Saini V, Yadav KS. Nephropharmacological activity of ethanolic extract Lipidium sativum L. Seeds in albino rats using cisplatin induced acute renal failure. Int J Pharm Sci Rev Res 2010;4:64-8.

52. Sharma M, Kishore K, Gupta SK, Joshi S, Arya DS. Cardioprotective potential of Ocimum sanctum in isoproterenol induced myocardial infarction in rats. Mol Cell Biochem 2001;225:75-83.

53. Arya DS, Nandave M, Ojha SK, Kumari S, Joshi S, Mohanty I. Myocardial salvaging effects of Ocimum sanctum in experimental model of myocardial necrosis: A haemodynamic, biochemical and histoarchitectural assessment. Curr Sci 2006;91:667-72.

54. Devi PU, Ganasoundari A, Vrinda B, Srinivasan KK, Unnikrishnan MK. Radiation protetction by the Ocimum flavonoids orietin and vicenin: Mechanisms of action. Radiat Res 2000;154:455-60. 